\title{
Towards a Psychopathology of Opera
}

\author{
Jeremy Tambling
}

Cambridge Opera Journal, Vol. 9, No. 3. (Nov., 1997), pp. 263-279.

Stable URL:

http://links.jstor.org/sici?sici=0954-5867\%28199711\%299\%3A3\%3C263\%3ATAPOO\%3E2.0.CO\%3B2-P

Cambridge Opera Journal is currently published by Cambridge University Press.

Your use of the JSTOR archive indicates your acceptance of JSTOR's Terms and Conditions of Use, available at

http://www.jstor.org/about/terms.html. JSTOR's Terms and Conditions of Use provides, in part, that unless you have obtained prior permission, you may not download an entire issue of a journal or multiple copies of articles, and you may use content in the JSTOR archive only for your personal, non-commercial use.

Please contact the publisher regarding any further use of this work. Publisher contact information may be obtained at http://www.jstor.org/journals/cup.html.

Each copy of any part of a JSTOR transmission must contain the same copyright notice that appears on the screen or printed page of such transmission.

JSTOR is an independent not-for-profit organization dedicated to and preserving a digital archive of scholarly journals. For more information regarding JSTOR, please contact support@jstor.org. 


\title{
Towards a psychopathology of opera
}

\author{
JEREMY TAMBLING
}

Roland Barthes discusses a postmodern condition in his last book, Camera Lucida: everything is signified and visible, and everything has the flatness of the photographic image; even death is rendered platitudinous, flat. If everything can be represented, nothing can be represented that would distinguish it from the mass of images already available; and if everything is for consumption in conditions of distraction, then difference disappears; we are left in a state Barthes calls 'indifference'. Barthes then looks for the punctum: any point of unrepresentability that will punctuate or pierce the smoothness of the studium (art marked out by completeness, by total visibility). The punctum, by its wounding quality, would be a signifier pointing to something outside representation, outside the studium, and inasmuch as opera in the condition of postmodernism is likely to be a saturated medium, absorbed by viewers and listeners in conditions of distraction, the question arises, what punctum could it bear? There is, of course, nothing that could be isolated as such: it is, rather, that which by being outside representation appeals to what might be called - adapting Walter Benjamin's sense of photography as pointing to an 'optical unconscious' - an 'aural unconscious' just outside the text. ${ }^{1}$

'Distraction' as used in the last paragraph evokes Benjamin's characterisation of the conditions in which film and other forms of popular culture are absorbed. Borrowing from the formulation that 'the masses seek distraction whereas art demands concentration from the spectator', Benjamin contends that in the cinema, 'the public is an examiner, but an absent-minded one'. ${ }^{2}$ He disagrees with Adorno on 'the regression of listening' that takes place in the fetishised music of the culture industry. Absent-mindedness has its dangers, as Peter Evans and Bruce Babington observe, referring to the 'potentially authoritarian' implications 'of valorizing states of distraction in the audience which the critic transcends in his paradoxically mindful praise of absent-mindedness'. ${ }^{3}$ And while their critique recalls Adorno's anxiety of the 1930s about the mutual fascination of mass or popular art and

1 Roland Barthes, Camera Lucida, trans. Richard Howard (New York, 1981), 26; for a further definition, see p. 51, 'the studium is ultimately always coded: the punctum is not'; pp. 96-7: the studium is the 'field of cultural interest' in, in this case, a photograph; the punctum is 'the unexpected flash which sometimes crosses this field'. For the flatness of the photographic image in Camera Lucida, see pp. 73, 92, 94 and 106. For Benjamin on the 'optical unconscious', see 'A Short History of Photography', in One Way Street and Other Writings, trans. Edmund Jephcott and Kingsley Shorter (London, 1978), 243. The phrase provides Rosalind Krauss with her title The Optical Unconscious (Cambridge, Mass., 1993), a text that indirectly influences this essay.

2 Walter Benjamin, 'The Work of Art in the Age of Mechanical Reproduction', Illuminations, trans. Harry Zohn (London, 1970), 243.

3 Bruce Babington and Peter Evans, A Night in at the Opera, ed. Jeremy Tambling (London, 1994), 150. 
fascism, the notion of 'distraction' would modify Brecht's characterisation of music as an addiction, with musicians as narcotics-dealers:

We see entire rows of human beings transported into a peculiar doped state, wholly passive, sunk without trace, seemingly in the grip of a severe poisoning attack. Their tense, congealed gaze shows that these people are the helpless and involuntary victims of the unchecked lurchings of their emotions... The worst gangster film treats its audience more like thinking beings ... Such music has nothing but purely culinary ambitions left. It seduces the listener into an enervating, because unproductive, act of enjoyment. No number of refinements can convince me that its social function is any different from that of the Broadway burlesques. ${ }^{4}$

Brecht here attacks the assumption that listening to art music involves the autonomous ego as watchful subject in a state of concentrated 'contemplation' (Benjamin's term). Instead, 'distraction' assigns a primary position to the body, not the ego, in the contemplation of art: no longer the servant of the cogito, the body that 'thinks' is impacted on when in contact with images or art forms that overturn the mind's capacity to organise perception. Contemplation and distraction bring into focus different attitudes to the body. In contemplation, the public sits through a symphony or opera with mind attentive and body mastered (no feet-tapping, no dancing or imaginary conducting, no walking around the room).${ }^{5}$ But mind and body are not neat opposites. Freud's unconscious splits up the concept of mind; distraction, in suspending the notion of the autonomous Cartesian ego, opens up the subject to the unconscious, including what I will call here the aural unconscious.

'Distraction' challenges autonomous high art, as does total visibility, the total slickness of opera presented with all the enframings of technology. Conditions of the postmodern elide reception of the popular and reception of art-culture: in fact they break down the distinction. Hans Pfitzner's contempt for the (then silent) cinema is no longer possible:

I only know that the cinema audience is completely different from that of the theatre ... In quick succession, voyeuristic pleasure is satisfied. But what is the cinema if not a theatre whose emphasis lies in the visual, even as music accompanies the viewed actions ... This music fulfils the base function of providing the listener with a certain rhythmic stimulation. ${ }^{6}$

Pfitzner separates the function of music in the cinema from its role in relation to the drama in opera, resisting the sexual overtones of cinema-going ('voyeuristic pleasure', 'stimulation') by claiming something else for opera audiences. Unfortunately for Pfitzner, such separation has long gone. Arguments from the postmodern would suggest that opera is characteristically consumed in a state of inattention even in the opera house, but more especially on video or television, or in extensions such as film scores, the narrative of films (Andrea Chenier in Pbiladelpbia), the place given to the three tenors or arias heard during the World Cup.

${ }_{5}^{4}$ John Willett, ed., Brecht on Theatre (London, 1964), 89.

5 Richard Leppert, The Sight of Sound: Music, Representation and the History of the Body (Berkeley and Los Angeles, 1994), 24-5.

${ }^{6}$ Quoted by Marc A. Weiner, Undertones of Insurrection: Music, Politics and the Social Sphere in the Modern German Narrative (Lincoln, Nebr., 1993), 68. 
The example that interests me here is the crossover between opera and musicals: opera stars who record CDs of popular musicals; opera houses - if only for budgetary reasons - that stage them; the London based monthly journal Opera that regularly reviews them. And I should immediately confess an ambivalence about musicals as an 'other' of opera. Unless they are by Lloyd Webber or Schonberg, where my dislike is primary and visceral, I usually begin by liking musicals and wanting to defend parts of them. Although I suggest a difference between opera and the film musical in particular at the end of this article, I concede that a basic distinction between them is impossible to maintain: it is not worth trying to argue that opera is inherently better or more serious, since musicals often have the defence that they work within operatic styles to parody them, thus polarising European opera against American music theatre.

Objections to musicals might arise from reflections on their mainstream musical style, their coerciveness as regards minority groups, their gender-stereotyping, middle-class appeal and WASP qualities. Take Jerome Kern's and Oscar Hammerstein's Show Boat, itself belonging to a mixed genre, as both theatre and cinema. Based on a popular novel by Edna Ferber, it is a white hegemonic text about the American South, recuperating blacks for white entertainment in the very decade of the Harlem Renaissance, and identifying them with suffering and acceptance. First staged in 1927, Show Boat was filmed in 1929, 1935 and 1951. Revived in America in the Reaganite 1980s as an opera, and by the British company Opera North in 1989 in a co-production with the Royal Shakespeare Company, the text was given a double coat of gloss as both opera and as theatrical classic. The 1989 production possessed, according to Max Loppert, 'the power and precision of opera-house ensemble at its best with the vigour and punch of a "real" musical'." (Even musicals are now simulacral, it seems: no longer real.)

Although Show Boat has associations with black culture, Kern went on record in 1924 as disliking jazz orchestras (and so black music): 'There is no such thing as jazz music per se, at least nothing that might be called original and characteristically American. The Gypsy orchestra of Hungary knew and used similar methods years ago, but they were artists and knew how and when to apply these methods. ${ }^{8}$ The politics of this approach seeks to define America with a hegemonic American music-something emphasised when Reagan pronounced Kern's centenary (27 January 1985) 'National Jerome Kern day'. But it is perhaps more relevant to tie these observations to the way that the lyrics and characterisation of Hollywood musicals, especially those whose topic is putting on a Broadway show, thematise American ego-psychology.

This is the American 'take' on Freud that reads the ego as the site of intentional consciousness and authentic self-possession, a reading that Jacques Lacan specifically works against, stressing the méconnaissance, the misrecognition that underlies the ego's perceptions, its fictional form and distorting function. ${ }^{9}$ In dealing with the

\footnotetext{
7 Opera, 41 (1990), 153.

8 Gerald Bordman, Jerome Kern, His Life and Music (Oxford, 1980), 250.

9 See John Gallop, 'The American Other', in Reading Lacan (Ithaca, N.Y., 1985).
} 
aural unconscious that destabilises the organicist ego, it is important to ask what unconscious drives motivate opera and musical forms. For if the Broadway or Hollywood musical asserts a hegemonic position (the status of the WASP ego), the confidence is still a matter of anxious desire, not an ability to enact that position confidently. Its utterances are performative, as in Show Boat's opening number for Gaylord Ravenal and Magnolia, 'Only Make Believe I Love You'. Gaylord is a gambler who has just been cleaned out. He wanders down to the river and on to the show boat, where Magnolia is acting to herself a part in melodrama (the ego established through performance). He interrupts, attracted to her in the context of a theatricality and illusion that both work like the Freudian unconscious, where there is no 'no', or like the dream, which is the fulfilment of a wish. In the 1951 film version directed by George Sidney, Gaylord (Howard Keel) 'tries on' a relationship - like trying on a dress - by singing as much to her dress as to Magnolia (Kathryn Grayson). ${ }^{10}$ The fetishism of singing to clothes is less important than the protection of 'make believe' on stage and off, though fetishism is itself a making believe, vital for the protection of male autonomy it simultaneously undercuts.

That undercutting relates to cinema, which has its own anxieties about status the medium may be defined in terms of absence, in which it is usually posited as being different from theatre. For film theorist Christian Metz, for example, reality in the theatre 'is physically present, in the same space as the spectator. The cinema only gives [reality] in effigy, inaccessible from the outset, in a primordial elsewhere.' Moreover,

During the screening of the film, the audience is present and aware of the actor, but the actor is absent and unaware of the audience; and during the shooting, when the actor was present, it was the audience which was absent ... The exchange of seeing and being-seen will be fractured at its centre. ${ }^{11}$

Whether or not this distinction is maintained in the Hollywood musical, cinema responds to the argument about absence by a diegesis stressing the immediate quality of 'putting on a show', as in Show Boat, where the narrative is of the theatre and its immediate presence (including the father coming on stage to encourage and dance with Magnolia when she is just starting out in Chicago).

Even more than the musical (especially the filmed musical), opera works by the illusion of immediacy and presence, something increased exponentially by the atmosphere and aura of 'the opera-house'. If musicals try to establish American ego-psychology, can anything be said about the psychoanalysis of opera, particularly as it is consumed today? The ego is associated by Freud with the body and with bodily awareness - 'the ego is first and foremost a bodily ego; it is not merely a surface entity, but is itself the projection of a surface'. ${ }^{12}$ Since the subject can exist only as a representation is placed before it, an art form (opera, theatre, cinema) that puts a hearer/viewer in front of actors, singers or dancers encourages identification

${ }_{10}^{10}$ Robert Altman, The American Film Musical (Bloomington, 1987), 85.

11 Christian Metz, The Imaginary Signifier, quoted in Barbara Freedman, Staging the Gaze: Postmodernism, Psychoanalysis, and Shakespearean Comedy (Ithaca, N.Y., 1991), 41.

12 Freud, 'The Ego and the Id', Penguin Freud 11: On Metapsychology (Harmondsworth, 1977), 364. 
with the representation offered as if in a mirror. The viewer occupies a split if illusory space, both in front of the representation and mirrored in it. According to Lacan's 'Mirror Stage', the subject that looks in the mirror is caught up by the power of the representation, which manufactures

for the subject, caught up in the lure of spatial identification, the succession of fantasies that extends from a fragmented body-image [the corps morcele] to a form of its totality that I shall call orthopaedic - and lastly to the assumption of the armour of an alienating identity. ${ }^{13}$

The 'lure of spatial identification' is suggested by the opera house, which gives the illusion of a sure, social identity by providing a space for the viewer from which to see the drama. But the subject tries to constitute itself as single because it has already been represented as a subject. Through 'the gaze' the subject is looked at, the gaze being the fetishising look that makes the subject complete and whole, a 'given to be seen'. The subject's primary narcissism comes about as a result of being looked at, from being in the field of vision. But the theatre is no place to sustain the subject's completeness; the critic Barbara Freedman argues that there is a sense of loss in the theatre equivalent to the cinema: 'the appeal of theatre ... depends upon an uncanny awareness of a fundamental loss in relation to the mirror image through which subjectivity is procured', because 'theatricality is a showing and if showing is a staging or displacement, then what one shows can never be that which is'. ${ }^{14}$

In Lacan, the subject surrenders the aim of finding a phallic completeness in the other via 'the gaze', replacing it by the objet petit $a$ - an investment in those parts of the body, including the voice, that speak of the border or the boundary between bodies. ${ }^{15}$ (Voices break down boundaries since sound does not respect borders: you can hear around corners.) What is seen is never what is: the non-coincidence turns back the 'scopic drive' behind both cinematic and theatrical viewing, and the theatre plays on this ambiguity of deferral, disorganising the field of perception by showing 'that it knows that it shows'. ${ }^{16}$ Freedman's argument relates to Shakespeare's comedies, which play tricks with the audience's perspective (seeing what is not there and not seeing what is there), but it can be tried out on opera. Is the gaze turned away, is there a recognition of the doubleness behind showing in opera? Is there a punctum to disturb the gaze, to puncture established representation? Although the images are perceptual, such a disturbance of the subject's gaze would come through operatic sound, implying an aural unconscious. Sound is appealed to by the subject in what Lacan calls the 'invocatory drive', 'the closest to the experience of the unconscious', which 'has the privilege of not being able to close'. ${ }^{17}$ As Friedrich Kittler puts it, sound 'pierces the armour called Ego, for among all of the sensory organs, the ears are the hardest to close'. ${ }^{18}$ Sound, which in the Hollywood musical

13 Jacques Lacan, Ecrits: A Selection, trans. Alan Sheridan (London, 1977), 4.

14 Freedman, 56, 52.

15 'The Subversion of the Subject and the Dialectic of Desire', Ecrits, 315.

16 Freedman, 70.

17 Jacques Lacan, The Four Fundamental Concepts of Psychoanalysis, trans. Alan Sheridan (Harmondsworth, 1979), 104, 200.

18 Friedrich Kittler, 'Weltatem: On Wagner's Media Technology', in Wagner in Retrospect, ed. Leroy R. Shaw, Nancy R. Cirillo and Marion S. Miller (Amsterdam, 1987), 222. 
is protective of the ego and feeds ego-psychology through its lyricism, can also be the force that fragments or pierces the subject. Unlike other organs of sense, the ear takes the outside into the inside; it possesses depth in relation to the body as other senses do not. The body is threatened in fantasy with fragmentation - as though sound could shatter it, as it does glass - and protects a sense of wholeness by being armoured as the ego. Discussion of the body and therefore of sexuality thus raises the question of what libidinal investment takes place in listening to opera. (Let Pfitzner stand for those who would deny that there is any.)

In cinema, the screen is analogous to the mirror, giving the viewer an identity (including gender-identity) secured through identification with sound. Other than musicals, few films thematise sound (Farinelli shows Handel's ego fragmenting as he listens to the castrato sing), but opera's subject inherently is sound. To discuss what identifications sound offers, or refuses, I will proceed from the film critic Kaja Silverman's locating of psychoanalytic drives within cinema viewing in aural identification, and will follow her by referring to three psychoanalysts in discussing how the female voice is heard in both opera and in the musical. ${ }^{19}$

Michel Chion's La Voix au cinema (1982) considers the voice of the woman as, in fantasy, engulfing and destructive, originary: 'in the beginning was the voice', so that the maternal voice is opposed to and prior to paternal meaning (the word). The mother's voice is on the inside; the fantasmatic task being to get outside its enveloping nature. Classic cinema - which for Silverman means cinema existing within the terms of patriarchy - is for Chion 'a machine made in order to deliver a cry from the female voice'. ${ }^{20}$ According to Chion, 'the point of the cry is an unthinkable point at the interior of thought, an inexpressible [point] at the interior of the enunciation, an unrepresentable point at the interior of representation ... This cry incarnates a fantasm of absolute sonorousness. ${ }^{21}$ The voice of the woman rendered as 'involuntary sound, sound that escapes her understanding, testifying only to the activity of a superior force', ${ }^{22}$ implies that the woman as 'other' is being taken over. Chion suggests through a reading of Citizen Kane how Kane's building of an opera house for his wife Susan is an attempt to enclose her voice. The distinction between sound and meaning, read here as male-female difference, may recall how Germont's voice entraps Violetta's in La traviata, ${ }^{23}$ or Kundry's cry when Gurnemanz pulls her out of the bushes and brings life back into her body in Parsifal. Kittler discusses Kundry's utterance 'as an hysterical speech disorder in the technical sense of psychoanalysis, i.e., as a separation between head and body, as the throat runs

19 The Acoustic Mirror: The Female Voice in Psychoanalysis and Cinema (Bloomington, Ind., 1988).

20 Silverman, 77.

21 Silverman, 77, emphasis mine.

22 Silverman, 77.

23 See Paul Robinson, Opera and Ideas: From Mozart to Strauss (Ithaca, N.Y., 1985), 168-77, for these 'power voices'. 
between them'. ${ }^{24}$ The throat's valence in psychoanalysis as the marker of sexual difference ${ }^{25}$ renders Kundry disorganised: she is the fragmented being who cannot establish a subjectivity, which is the source of her melancholy and her silence in Act III after her cry and the words 'Dienen ... dienen'. The narrative of the scene, with Parsifal's purification and crowning, further marginalises her: her very muteness excludes her from the sphere of representation. But this makes her cry significant. To the extent that the cry indicates the unrepresentable, not part of the order of patriarchal signification, we may recall that Schopenhauer contended music was 'a representation to that which of its essence can never be representation ... music [is] the copy of an original that can never itself be represented'. ${ }^{26}$ Music, then, gestures towards the unrepresentable. But what is outside representation?

What cannot be represented - that which Kundry embodies - is the reverse of the purity evoked in the last bars of Parsifal; it is what Julia Kristeva calls the abject, outside representation, and the subject of repression. ${ }^{27}$ Abjection involves a pre-Oedipal attempt by the child to separate itself from the mother in order to establish borders; hence the hostility to things associated with bodily limits and borders (blood, filth, anything that flows) because these question the border and the possibility of a separate self. Inability to separate fully from the mother is paradigmatic of a fear of the Other - that which contaminates the self and its separateness. The subject is identified both with what it repudiates and what is repudiated: not subject but abject. Kundry is the abject in being the body: although Parsifal involves redemption of a body, this does not affect Kundry, separation from whom also repeats aspects of Parsifal's initial separation from his mother, with whom she identifies in her seduction scene in Act II. Erotic singing, focusing on the mouth, pairs with the attempt to kiss - to force the mouth on to Parsifal's body. Sound, mouth and body unite in a kiss that makes Parsifal sing immediately of 'die Wunde!' He continues with the fantasy that the wound bleeds in himself, as though the kiss created him as a body in pieces. It is as though he fears his body is about to be devoured; as if, in a two-way operation, the power of the voice singing out from the mouth is inseparable from the mouth sucking in, cannibalistically. ${ }^{28}$

The attempt to force representation into the open may be seen at the end of Salome, where it seems as if Kundry takes revenge on a mocking, castrated Klingsor, already a body in pieces. Salome sings her last solo to part of a corps morcelé: to the head of John the Baptist, brought to her on a plate as though to be eaten; to the man

24 Kittler, 263.

25 Adrian Leverkühn in Doctor Faustus aligns the singing voice with the pudendum; see Thomas Mann, Doctor Faustus, trans. Helen T. Lowe-Porter (Harmondsworth, 1968), 70.

26 Arthur Schopenhauer, The World as Will and Representation, trans. E. J. Payne (New York, 1957), I, 257. Compare this sense of the unrepresentable in consciousness being brought to music with Wagner's in Opera and Drama: 'one characteristic of the more developed human being of the future will be his consciousness of the unconscious'. See Bryan Magee, The Philosophy of Schopenhauer (Oxford, 1983), 340.

27 Julia Kristeva, Powers of Horror: An Essay on Abjection, trans. Leon Roudiez (New York, 1981).

28 On this interrelationship between the voice and cannibalism, see Mikhail Yampolsky, "Voice Devoured: Artaud and Borges on Dubbing', October, 64 (1993), 57-77. 
who, as complete body and narcissist, would not allow himself to be touched. Herod commands the torches to be put out, so that Salome's last words ('Ach! Ich habe deinen Mund geküsst, Jokanaan') are sung in darkness. But then a moonbeam covers her with light, and Herod demands - speaking, not singing - that she be killed. The soldiers crush her with their shields. The end thus plays with two motifs: visibility and invisibility, what is and is not represented, what is and is not sung. For Herod, whose own sexuality and therefore ego and subject position are also in question, what Salome sings is the unrepresentable. His turn to speech is inherently repressive in bringing back into non-representation the unrepresentable but shockingly represented - the fragmented male body and the woman whose identification is with music, her own subject-position split between the sadism that has ordered the body to be rendered in pieces and the love that wants it like that. The opera closes with a 'militaristic gesture', ${ }^{29}$ with the autocrat's ego that must armour itself if only with the shields that crush Salome.

Guy Rosolato, who provides me - via Kaja Silverman - with a second example of psychoanalytic thinking, insists on the plenitude of the maternal voice, associated with memories anterior to sight and presence: the voice as lost object. Rosolato uses the phrase 'acoustic mirror', which Silverman adopts for her title, suggesting that 'the voice emitted and heard, [is] sent and received by the object itself, as if, in comparison to the look, an "acoustic" mirror were always in effect'. ${ }^{30}$ In contrast to the discrete nature of the look, sound enwraps the subject in a fantasy of completeness. This reading - of the voice as mirror by which the subject establishes his or her own subjectivity ${ }^{31}$ - is also marked by two other qualities: signs of a pre-symbolic otherness, and being both inside and outside together, in a realm of undecidability. Neither inside nor outside, it challenges borders and boundaries, and so challenges abjection, the fear of not establishing such borders. In the realm of the aural, the subject cannot define itself in singleness, and this relates back to the otherness heard in the voice itself. Silverman argues that 'the female voice can become the dumping ground for disowned desires', ${ }^{32}$ suggesting that the female voice in opera could be thought of in several ways:

(1) As the abjected element thrown out in order to establish subjectivity. This would make it feared, despised, dreaded, an object of horror, causing gagging, and violent reactions of non-assimilation, just as it arouses fantasies of devouring.

(2) As the maternal that is sought after and identified with as the objet petit a, that which establishes a fantasmatic subjectivity.

(3) As the element that questions the autonomy of the subject, the ego, which negates and confirms it at the same time.

${ }^{29}$ Leppert (see n. 5), 15.

30 Rosolato, quoted in Silverman, 80.

31 Robert Lang, 'Carnal Stereophony: A Reading of Diva', Screen, 25 (1984), 70-7.

32 Silverman, 81. 
The ambiguous nature of the voice, as it evokes or emanates from, resonates in Offenbach's Tales of Hoffmann (1881) when Hoffmann falls in love with the musician Crespel's daughter, Antonia, whose mother was a famous singer. Crespel cannot bear it when Antonia sings, because he hears the voice of her dead mother (there is a full-length portrait of the mother on the wall, as though mirroring Antonia). Hoffmann, no less patriarchal, says he will not let Antonia sing when they are married for fear of her yielding to the 'demon of music'. Dr Miracle, whom Crespel believes responsible for the death of his wife, seems to be that demon, since he appears when Antonia is alone, and tries to persuade her to sing. When she refuses, he makes the portrait of the mother do so - 'Chère enfant, que j'appelle comme autrefois, c'est ta mère, c'est elle, entende sa voix'. Antonia begins to sing, the rapid increase of emotions heard in the duet becomes a demonstration of excess, and she expires with her 'chanson d'amour'.

The song that opens the act, which has been called the only sad one Offenbach wrote, ${ }^{33}$ is described by Hoffmann as 'triste ou folle' and is associated with the mother. As the curtains open, Antonia is singing it, declaring how the turtle dove has flown. This suggests the woman's departure from her lover, but then the narrative within the song becomes the woman's as she says that her voice is calling and asks if 'he' loves her still. This may refer to Crespel's separation of Antonia and Hoffmann, but it also seems to be the mother's song, raising issues about the independence of the woman with regard to the man, especially as she sings at the end 'Et lui ... de retour', leaving the 'he' unidentified (it certainly goes well beyond Hoffmann). The 'he' is the emblem of the other that cannot be captured in any attempt to suppress the voice of the woman.

The Tales of Hoffmann is melancholic throughout, not only in recording the deaths of each of the women who try to make love to Hoffmann, but also in recording a series of failures by the text's narrator, crossed every time he tries to make contact with a woman. Perhaps, as Kracauer suggests, the text is autobiographical, ${ }^{34}$ and the desired woman is opera as opposed to operetta; but she can never be possessed, which ultimately implies that the ideal cannot exist in a state of purity - that opera, at least now, cannot exist outside something more meretricious, like the musical as opera's 'other'. Another reading might be that Hoffmann, as a composer figure like Antonia's father, comes between her and her pleasure, and that his anxiety is the source of her death and his disempowerment, his virtual castration. From the beginning, the opera uses fantasies of Lacan's corps morcelé. The first woman Hoffmann loves, Olympia, is a doll and is smashed; the fantasy-image that should feed his narcissism is not a body at all. In the second scene, Hoffmann loses his reflection in the glass - his

33 Alexander Faris, Jacques Offenbach (London, 1980), 213.

${ }^{34}$ Siegfried Kracauer, Offenbach and the Paris of his Time (London, 1937), 327-38. Kracauer sees Offenbach as doubling Hoffmann in his wish to compose opera and identify with Mozart (338). The death-wish in the text 'laid bare the dark foundations out of which the operetta had grown, and thus showed their depth' (343). On the 'Antonia' scene, see Heather Hadlock, 'Return of the Repressed: The Prima Donna from Hoffmann's Tales to Offenbach's Contes', this journal, 6 (1994), 221-43. 
narcissism and his whole sense of subjectivity and ego, premised on having a body - while Giulietta dies of poison.

But in the fourth scene (assuming the traditional arrangement of acts) the males take revenge on sound and the mother as though feeling the threat to their separate subjectivity. The association of sound with excess is also with feminine sexuality. Crespel and Hoffmann seem to fear this: Miracle taunts Antonia that she will have only 'les plaisirs bourgeois' when she marries. But feminine sexuality is awakened by the mother, fetishised as a picture (represented in one way, but excluded in another, since her daughter's voice must not be heard). At the end, mother and daughter sing together in a plenitude in which their voices cannot be distinguished, this excess destroying the boundaries that make for abjection and so for the exclusion or taming of representation. In this sense, The Tales of Hoffmann works against abjection by trying to bring back the mother. Yet the excess also destroys such an enlarged representation: the mother supports the daughter in her narcissistic abandonment of herself to pure song, acting like the mirror to her. The picture glows as the mother sings - as though it belongs to the pre-history of cinema, ${ }^{35}$ but the identification that gives the daughter a body and an ego through the power of sound - as though the sound were the body - cannot be sustained. The daughter collapses and dies; the sound contains its own sense of loss. In repeating the mother's music, as Wayne Koestenbaum puts it, 'the opera signifies remembrance'. ${ }^{36}$ Though the melody is tied to excess, it is also inseparable from the mournfulness of broken memories.

Such a display of the woman undone by the very process of singing is basic to much opera, as if there were a relationship between the melancholic position of loss that characterises the drive to watch and listen, and the discovery of melancholy within the text. But the term 'melancholy' should not be reduced to nostalgia or depression: it comes from a recognition that pure subjectivity is an impossibility, contending against an idealism based on the idea of a totalisable metaphysical statement emerging through the work of art. In his essay 'Bourgeois Opera', Adorno comments that 'opera, hardly touched by philosophy, has sustained itself on metaphysics more than drama, which contaminated its metaphysical content with conceptual contents' ${ }^{37}$ Melancholy would enable a sense of the fragment, or the ruin, suggesting that any complete representation collapses because of what is left out.

35 With this fantasmatic body, compare Adorno, who argues that male voices sound better disembodied, on record, than women's: 'In order to become unfettered, the female voice requires the physical appearance of the body that carries it. But it is just this body that the gramophone eliminates, thereby giving every female voice a sound that is needy and incomplete. Only there where the body itself resonates, where the self to which the gramophone refers is identical with its sound, only there does the gramophone have its legitimate realm of validity: hence Caruso's uncontested dominance.' Theodor W. Adorno, 'The Curves of the Needle', trans. Thomas Y. Levin, October, 55 (1990), 54.

36 Wayne Koestenbaum, The Queen's Throat: Opera, Homosexuality, and the Mystery of Desire (New York, 1993), 222.

37 Theodor W. Adorno, 'Bourgeois Opera', in Opera Through Other Eyes, ed. David J. Levin (Stanford, 1994), 34. 
If what is outside representation in music, and ambiguously signalled to by it, is repressed material, we might next consider Adorno's comments on Schreker, whom the Nazis declared degenerate. Adorno calls Schreker's work de-centred, drawing on Freud's 'Civilisation and its Discontents', which sees sexual drives as fundamentally opposed to those that are cultural. Their dysfunctional nature leads to the repression imposed by civilisation, but at the same time, repression of the sexual only awakens its drive, perpetuating a spiral of discontent. Adorno says that Schreker's music 'failed to construct an ego':

It stands outside the demands of culture. But because it springs from a compulsion which is more potent than shame, and testifies to the truth of things that culture proscribes, it gives expression to doubts about the value of culture as such. Schreker consciously deserts to this realm which culture has distanced itself from and consigned to the vulgar. The fact that culture has to reject this reminds us of the limitations of its power and ultimately of its own failure, unable to effect a reconciliation between the drives and itself, it holds them down by force. This has led to those increasingly powerful feelings of discontent which Freud described in that late essay. Schreker . . refuses to join in the repression of the drives. ${ }^{38}$

There is nothing in Schreker of ego-psychology: establishing an ego is akin to using opera for metaphysics - the attempt to stabilise the subject on the basis of excluding otherness from it, on the basis of abjection. Schreker's operas critique the smooth surface of the life and death drives; they aim at what is not represented in culture. Adorno's reading makes Schreker overturn his own negative comments on the culture industry by seeing art culture in terms of a repression that popular or 'vulgar' culture allows to the surface. Schreker could never have written a musical popularising ego-psychology, but as Adorno said somewhere that nothing in psychoanalysis was true except the exaggerations, his argument also suggests that looking at popular culture for its use of psychoanalytic material allows for no sublimation or repression of the sexual drives.

This would encourage a return to Show Boat, and to the musical's deployment of the female voice. The leading lady on the show boat is Julie, a product of miscegenation, her mother being black. When she has to leave the boat, the parts she has played are taken over by Magnolia, the white amateur who acts her parts by acting - that is, making believe she can act (important encouragement for the ego in its self-expression). Julie's marginal character is hinted at in her 'Can't help loving', which uses blues rhythms (the 1951 version was sung by Lena Horne as recognisably black music, slowly and with vocal slides; Ava Gardner was dubbed). The newly married Magnolia and Gaylord go to Chicago, where he leaves her after running up gambling debts; she returns to show business with her new-born daughter, Kim. Gaylord is reconciled with his wife through the daughter at the end. In the 1951 film, he learns of the daughter's existence through Julie, now a drunk, abandoned by her former lover and associating with white trash. Julie has before this backed out of a show in Chicago, in order to give the deserted Magnolia the chance of getting back into show business. In the penultimate scene of the film, Julie, who in the novel ends as a prostitute, speaks to Gaylord, who does not

38 Theodor W. Adorno, Quasi una fantasia, trans. Rodney Livingstone (London, 1992), 143. 
recognise her but has helped her against her partner's violence. In return, she calls him a rat, and when he agrees with this description, in her abjection she also applies it to herself: - 'Lots of rats come off showboats - sneaking off, kicked off. When he learns the truth, she finishes 'Don't ever tell her [Magnolia] you saw me like this'.

The scene sets up mirroring relationships. Julie's new partner keeps coming into the scene as a mirror to Gaylord of what he is; she parallels Magnolia, to whom she has already twice given the big chance. The camera, by putting Julie to the left of the screen and Gaylord to the right, makes them mirrors of each other, both excluded: he, too, has walked away from Magnolia, leaving her alone, but also leaving her free to follow her career. None the less, this mirroring is deceptive, for he is bound for reunion with the show boat and with Magnolia, while Julie - a Strindbergian Miss Julie indeed - is destined for further exclusion. Her colour is overdetermined by her drunkenness, and relates to the way she is treated sexually; but then she internalises her marginalisation: her line 'You shouldn't have been nice to me' reads as though she saw it as her opportunity to be sadistic or more rat-like, accepting exclusion from the communal relationships of the show boat. She is like Kundry, who also raises fears of miscegenation (a new word, first appearing in 1864): she voices the split subject characteristic of hysteria when she talks in one way to the male but means another. The comparison with Kundry also comes forward when we consider the relation of these abject subjects to their respective texts. Both Parsifal and Show Boat, with different politics - Germany in the 1880s, the USA in the 1920s and 1930s - and different ideological structures activating them, show the secure ego-position from the foreign 'other' body, Silverman's 'dumping ground for disowned desires'.

The text represses the woman's abjection, hence the abject status of those outside the dominant WASP formation and the conditions of abjection that make possible its formation in the dominant ego. Though black, Julie appears as white, so that there is no marker of difference; the scene has no song, as though the musical form could not handle the voice of the abject and the marginal, and the text must focus on the woman who each time walks into success through only making believe. Although the mirrors seem to parallel Julie and Gaylord, only the former is destined to become increasingly unrepresentable. Her first big number, 'Can't help loving that man of mine', is immediately recognised by the other characters as black music, but is then taken up by Magnolia and becomes her leitmotif, recognised as such by Gaylord. It loses its black origins, thus de-centring Julie; but in any case, its cheerful diatonicism contrasts with its giving voice to a melancholic subject-position.

Melancholia for Freud is 'a profoundly painful dejection, cessation of interest in the outside world, loss of the capacity to love, inhibition of all activity, and a lowering of the self-regarding feelings to a degree that finds utterance in self-reproaches and self-revilings, and culminates in a delusional expectation of punishment'. ${ }^{39}$ The Freudian melancholic is wounded narcissistically, cannot sustain a sense of being a whole subject. Not everything said by Freud fits Miss Julie, unless we read against her text, but the wish to punish the self, heard even in such lines

39 Freud, 'Mourning and Melancholia', in Freud (see n. 12), 252. 
as 'Maybe I'm crazy - maybe I know', is there throughout - in her attitude to her man, her retreat before Magnolia, her shame at being known by her, her self-hatred. For Show Boat to articulate these feelings by giving music to the scene between Gaylord and Julie would not only have offended against its desire to centre the text around white success: it would also involve admitting that its own narcissism (which fits the ego-psychology) had been bought at the price of a repression of otherness; that white narcissism is dependent on the non-representation of the abject black. The extent of this repression might become a reason for finding the music of Show Boat too remorselessly determined to strike a happy or exalted metaphysical note, classically in 'Ol' Man River', which aims at the American epic and American opera, with blacks serving whites. But if we read Show Boat as a repressed melancholic text, other things follow: when Magnolia sings with Gaylord 'Lovers find peace of mind in pretending', ego-psychology takes a knock; love is declared to be nothing more than performance, a confession that there is no 'other' there, that the romance Hollywood celebrates is no more than a prop for narcissism.

Critical writing on the Hollywood musical asserts that it makes sound spectacular, most distinctly in the dance, as the 'natural' fulfilment of the development of sound and its aura. Silverman discusses this aura when she refers to the last of the three psychoanalysts I want to discuss: Otto Isakower, who in 1939 used Freud to suggest that the superego - that which is both inside and outside - is brought about through the process of listening. Isakower argues that language is perceived as coming from the outside, from the 'auditory sphere' or from the 'aura', where a word is heard before it can be articulated by the subject, and that 'just as the nucleus of the ego is the body-ego [in Freud], so the human auditory sphere is modified in the direction of language, is to be regarded as the nucleus of the super-ego'. ${ }^{40}$ This argument implicitly asks who has the superior speech and whose hearing can most exclude or make marginal other voices. Silverman uses the theory to ask about the possibility of the male subject freeing itself from regulatory female voices, about the female voice being capped by the male. She links the commanding nature of the voice to the fact that the narrative voice-over in classic cinema is usually male, whereas in Western culture the woman is characteristically the first teller of stories. It might be interesting to relate this point to opera by asking about the relation of orchestral sound as narrator to the events and singing on stage. We might think of Isolde: 'Höre ich nur / diese Weise, / die so wunder- / voll und leise, / Wonne klagend, / alles sagend, / mild versöhnend / aus ihm tönend, / in mich dringet, / auf sich schwinget, / hold erhallend, / um mich klinget?' (Do I alone hear this melody, so wondrously and gently sounding from within him, in bliss lamenting, all-expressing, gently reconciling, piercing me, soaring aloft, its sweet echoes resounding about me?). Here, as the voice disappears beneath the orchestra, there is an implicit equation between sound and aura, invisibility and narcissistic investment in a visible

40 Silverman, 98. 
and inaudible sound associated with the dead Tristan, the objet petit $a$. And if the sound is identified with Tristan, it is gendered as male, and as such pierces, fragments and obliterates the female subject. The impulse towards amplification would then become a masculine drive. Listening to the sense of Isolde's words, we can well imagine that Wagner would have been intensely interested in the idea of sound amplification.

Sound attains more resolution - as it were, glows more - with the advent of technological reproducibility. In Composing for the Films, Adorno and Eisler suggested that sound worked to stabilise the subject. In contrast, Hofmannsthal, writing a little earlier, in 1921, commented on silent films as deeply satisfying: 'the fact that these images are silent is an even further attraction; they are silent, like dreams. And deep down, without realising it, these people fear language; they fear in language the mechanism of society. ${ }^{41}$ Here the subject is not to be stabilised, for that would introduce the power of the superego, and would mean the investment of technology in producing the single subject (as indeed, historically, it has done: think of the reliance of fascism on technology). Adorno, however, had no time for the idea of a putative freedom within silent cinema, in which 'the people recognised themselves as just such beings, alienated from themselves and not far from being struck dumb'. ${ }^{42}$ Silent cinema confirms the identity of the subject as already mechanised, rendered mute-sound could give only false consciousness, allaying fears of alienation: 'the magical function of music [in the sound-track] consisted in pacifying the evil spirits in the unconscious perception [of film]'. ${ }^{43}$ Adorno sees sound as auratic, magical, his argument being that music 'gives film a nearness'. ${ }^{44}$ But this, while it contrasts with arguments about alienation, fits with the notion that sound relates to lack, its libidinal importance being that it restores a sense of presence. It links with his characterisation of opera as 'the specifically bourgeois genre which, in the midst and with the means of a world bereft of magic, paradoxically endeavours to preserve the magical element of art'. ${ }^{45} \mathrm{~A}$ musical diegesis, whether in opera or the musical, becomes incantatory, an attempt to re-enchant the world.

Opposed to the silent film, which renders the audience mute, the auratic sound film centres the subject and imposes on it the power of the superego while keeping audiences in a single subject position. It is ironic that Benjamin, who preferred silent cinema, should write about the decline of aura in the decade that mechanical reproduction gave the opportunity for its reintroduction. Mechanically produced sound can be seen as at once auratic and non-auratic: these contrasted ways of reading silent cinema versus sound cinema suggest that sound stabilises and de-stabilises at the same time. It suggests, following Rosolato, the power of the

41

42

43

44

${ }^{4}$ Adorno, 'Bourgeois Opera', quoted in Levin, 29. The contention literalises Weber's arguments about the 'disenchantment' of the world in the conditions of rationalising, and of social conditions being increasingly administered. See Anthony J. Cascardi, The Subject of Modernity (Cambridge, 1992), 16-71. For Adorno and Weber, see Max Paddison, Adorno's Aestbetics of Music (Cambridge, 1993), 135. 
mother, outside representation; but the mother it evokes is defined by loss, or is as in Offenbach simply dead: uncanny (unfamiliar and familiar) in Freudian terms, and mute on the wall until the aura plays on it when the portrait is lighted, and in this kitsch form appears to sing, as though conjured into doing so by the power of the cinema. Its uncanny nature is at once embodied and disembodied - suggesting Freud on the subject of castration as the fear of loss of total mastery, of ego-possession, just as he defined the death drives in terms of muteness, of silence.

One more twist to an argument about muteness. The word 'mute' is evoked in the writings of Paul de Man, whose reading of Wordsworth makes it resonate with death and - through a punning discussion - with 'mutilation' ${ }^{46}$ Muteness within Wordsworth, brought on by moments of shock, makes de Man read him in terms of disconfirmation and melancholia. Muteness then becomes ambivalent: linked with the subject's overthrow and death, a liminal position that works against speech as something complacent, self-confident and full of itself. Muteness is the punctum within speech, and is part of an undoing of the subject. Mutilation, as a form of muteness, returns to the subject of the corps morcelé, to the doll Olympia being torn in pieces.

If we associated Adorno with de Man, we could say that the identifications involved in sound come about from fear of being struck dumb, another aspect of fragmentation. In that sense, an investment in both voice and opera implies an anxiety about the preservation of subjectivity, establishing presence if only through the fantasma of disembodied sound. So the popular musical goes in for amplification and for miking (no room for muteness here), while the purity of the operatic voice, singing out as it does, seems to transcend the limitations of the body and cancel space, enforcing the suggestion of opera as an art that must be heard contemplatively in the opera house. Insistence on the purity of the voice tries to overcome the unconscious threat of muteness, even though this contemplation of vocal aura is in any case now becoming obsolete: the aura is now established technologically, in conditions of absence, through reproduction and amplification, through the perfection of the $\mathrm{CD}$ and laser disc.

In 'The Work of Art' essay, from where so much of this is drawn, Benjamin makes several moves: discussing cinema as the art of mechanical reproduction, he thinks of montage, which in turn suggests fragmentation of wholeness and the experience of shock, inverting the whole Cartesian mind-body relationship. 'Technology has subjected the human sensorium to a complex kind of training', Benjamin argues, ${ }^{47}$ to a receptivity to stimuli that makes film, which works entirely by shock, the most fitting twentieth-century medium. In this situation, experience must be redefined. Both Benjamin and Adorno discuss two types of experience:

46 Paul de Man, 'Autobiography as De-facement', in The Rhetoric of Romanticism (New York, 1984).

47 Walter Benjamin, Charles Baudelaire: A Lyric Poet in the Era of High Capitalism, trans. Harry Zohn (London, 1973), 132. 
Erlebnis (lived experience) and Erfabrung (experience that can be grasped whole). The greater the shocks of modern life, the more the human system protects the self against them: both Freud and Benjamin argue that in conditions of shock, consciousness, which absorbs the experience, blocks off memory. Using Proust, Benjamin argues that 'only what has not been experienced explicitly and consciously, what has not happened to the subject as an experience, can become a component of the mémoire involontaire' - the memory Proust values so highly. ${ }^{48}$ This, of course, is one up for distraction. According to Benjamin:

The greater the share of the shock factor in particular impressions, the more constantly consciousness has to be alert as a screen against stimuli; the more efficiently it is so, the less do these impressions enter experience [Erfabrung], tending to remain in the sphere of a certain hour of one's life [Erlebnis]. ${ }^{49}$

Shock induces in the self-conscious subject a defensiveness against sudden impact, so that it is not felt and the experience remains temporary, fragmented, not conceptualised. The defensive, self-protective state armours the ego, while the ego that can let go of its single-subject position is more likely to conceptualise experience. This suggests that art experienced in contemplation can be repressive, in that contemplation keeps out shock and anything that would disconfirm the ego. Distraction - Adorno's famous 'regression of listening' - becomes the only way in which the work of art can be received, suggesting that only here can be laid down a memory not positivistically related to experience.

Shock tending to dissolve the centred subject is basic to Wagnerian and post-Wagnerian opera; Joseph Kerman punned better than he knew in calling Tosca a shabby little shocker. The sense of shock lays down the last form of the aural unconscious I want to refer to. To be sure, few people read opera in terms of shock, and perhaps something in the nature of theatre dulls such a perception. Show Boat as a film looks more conservative than twentieth-century operas, for if modernity and shock work together, they do so in the city and crowd, not on the Mississippi: the musical makes Chicago the place of loss and anomie (no homes but hotels and boarding houses and the ruinous presence of gambling, which Benjamin connects entirely to the notion of shock). ${ }^{50}$ The characters escape from 1890s Chicago, rendered in the atmosphere of the 1920s, to the nostalgia of the show boat, to a small-town or rural culture that has lost its survival value. Yet we should not be deceived: Show Boat has absorbed the experience of shock by its use of high resolution and total clarity in its aural technological capacity. The musical is completely shock-ridden; it has gone beyond shock. Perhaps the value of technological reproducibility for opera - following on from the musical - would be to open up questions of shock that are not much tested in the theatre, with its non-amplified sound, slower pace and a set of codes that do not conflict with each other or over-code the communication. Such an experience in opera might also

49 Ibid., 117. For Adorno on these terms, see Paddison (n. 45), 213-16.

50 Benjamin, Baudelaire, 134. 
point to the unrepresentable, through establishing a different form of reception, and could prove the punctum to disturb the carefully formed and articulate ego.

What we go to opera for is something unattainable and unobtainable, but may involve in sound the object of desire that guarantees the subject's existence by being the objet petit a. Yet in the same way it may produce repulsion, or abjection, feelings of horror at the bodily image being shattered, fragmented, as though the subject were being taken into the unrepresentable, outside the field of acceptable vision. However, according to Lacan that self-confirming image received from the mirror was itself alienating. There is no meeting point between the desire to look and listen in order to confirm subjectivity, and another impulse that disconfirms this. I will close, though, with reference to Lacan on another art form, on painting as a form that both allows the gaze and arrests it through a stress on the materiality of paint. It helps to suggest something of the importance of the field of vision, so it may help analogously in considering a related field - that of the auditory:

The painter gives something to the person who must stand in front of his painting, which ... might be summed up thus: You want to look! Well, see this. He gives something for the eye to feed on, but he invites the person to whom the picture is presented to lay down his gaze there, as one lays down one's weapons. This is the pacifying, Apollonian effect of painting. Something is given not so much to the gaze as to the eye, something that involves the abandonment, the laying down of the gaze. ${ }^{51}$

In calling art Apollonian, Lacan distinguishes it from the Dionysian. No one is to be torn in pieces: there will be no corps morcelé. The ego, complete armour and self-protective, is invited to 'lay down its arms', to see what it would like to have excluded from representation. Lacan invests in the text's power to prevent the viewer or listener bringing only to the work the desire to have a dominant subject position confirmed; to turn it back, and by doing it as the punctum, to wound healingly, so that the subject does not recoil back in horror, as Parsifal did.

51 Jacques Lacan, The Four Fundamental Concepts of Psychoanalysis, 101. 